\title{
Linking smallholder agriculture and water to household food security and nutrition
}

\author{
FAM Wenhold ${ }^{1 *}$, M Faber $^{2}$, W van Averbeke ${ }^{3}$, A Oelofse $^{4}$, P van Jaarsveld $^{2}$, \\ WS Jansen van Rensburg ${ }^{5}$, I van Heerden ${ }^{6}$ and R Slabbert ${ }^{3}$ \\ ${ }^{1}$ University of Pretoria - Division Human Nutrition, Faculty of Health Sciences, PO Box 667, Pretoria 0001, South Africa \\ ${ }^{2}$ Medical Research Council, Nutritional Intervention Research Unit, PO Box 19070, Tygerberg 7505, South Africa \\ ${ }^{3}$ Centre for Organic and Smallholder Agriculture, Department of Crop Sciences, Tshwane University of Technology, \\ Private Bag X680, Pretoria 0001, South Africa \\ ${ }^{4}$ University of Pretoria - Centre for Nutrition, Faculty of Natural and Agricultural Sciences, Pretoria 0002, South Africa \\ ${ }^{5}$ Agricultural Research Council - Vegetable and Ornamental Plant Institute, Private Bag 293, Pretoria 0001 South Africa \\ ${ }^{6}$ Agricultural Research Council - ANAPI, Meat Industry Centre, Private Bag X2, Irene 0062, South Africa
}

\begin{abstract}
Promoting household food security and reducing malnutrition rates of a growing population with the same amount of water is a challenge facing South African nutritionists and agriculturalists alike. Apart from non-food related effects of agriculture in general, the crop and livestock production practices of the South African smallholder farmer may have nutritional implications, primarily when practised on residential land and resulting in home consumption. Yet, few studies have systematically investigated the impact thereof. It appears that crop diversification, gender issues and nutrition education are among the important factors that strengthen the link between agriculture and nutrition. Since food production is the most water-intensive activity in society, nutritional water productivity (i.e. nutrition per volume water) of foods and the nutritional water footprint of diets should be investigated in order to achieve a sustainable solution. This implies that both the demand for a diet consisting predominantly of water-productive plant products, as well as the supply thereof, be addressed.
\end{abstract}

Keywords: household food security, agriculture, water, nutrition, malnutrition, South Africa

\section{Introduction}

Finding appropriate and effective ways to reduce the prevalence of malnutrition in Africa, including South Africa, remains a challenge for nutritionists and agriculturalists. Growing populations and dwindling resources accentuate the challenge. Water is one of the essential resources in food production, making it a critical factor in food security. Achieving food security of growing numbers of people with the same amount of water thus is an important societal concern.

The overview of the nutritional status of South Africans, including dietary intake, by Faber and Wenhold (2007) identified over- and under-nutrition as public health concerns. They reported that at national level, more than half of South African females were overweight or obese, while substantial numbers of children suffered from various forms of under-nutrition. The prevention of malnutrition requires the causes to be identified and addressed, particularly in the case of children. According to the UNICEF conceptual framework reproduced and discussed by Faber and Wenhold (2007), under-nutrition in children is a manifestation caused, on the one extreme, by inadequate dietary intakes as a result of household food insecurity, which in turn is causally related to inadequate food production and other ways in which food is acquired. On the other extreme, diseases, exacerbated by insufficient health services and an unhealthy environment, can also result in malnutrition. Both of these underlying

\footnotetext{
To whom all correspondence should be addressed.

causes of malnutrition are interconnected with maternal and child care and education as intermediaries, and both are influenced by water as one of the essential resources.

The objective of this paper is to provide an overview of the links between, on the one hand, smallholder agriculture and water, and, on the other hand, household food security and nutrition, referring mainly to the South African context.

'Food security exists when all people, at all times, have physical and economic access to sufficient, safe and nutritious food to meet their dietary needs and food preferences for an active and healthy life، (FAO, 1996). It includes an adequacy and a stability dimension (Fig. 1). For food security to exist, food must be consistently available and accessible, and be properly utilised on the biological level.

De Klerk et al. (2004) classified South Africa as 'food secure'on the national level, but pointed out that more than $14 \mathrm{~m}$. people ( $\pm 35 \%$ of the population) might be vulnerable to household food insecurity. Using South African food balance sheets for 1998/99 supplemented with dietary surveys to determine changes in food security, Steyn et al. (2001) concluded that large sectors of the population were food insecure. Equally, based on Statistics South Africa's household-based 1995 Income and Expenditure Survey and the national market-based household subsistence level for that period Rose and Charlton (2002) estimated the prevalence of food poverty to be around $43 \%$. It follows that the country as a whole can produce enough food to feed the nation, but pockets of food insecurity are common.

A key food security challenge is to empower citizens to make optimal choices for nutritious and safe food (Department of Agriculture, 2002). This calls for an intensified, dedicated collaboration between agencies that advocate proper nutrition (for 


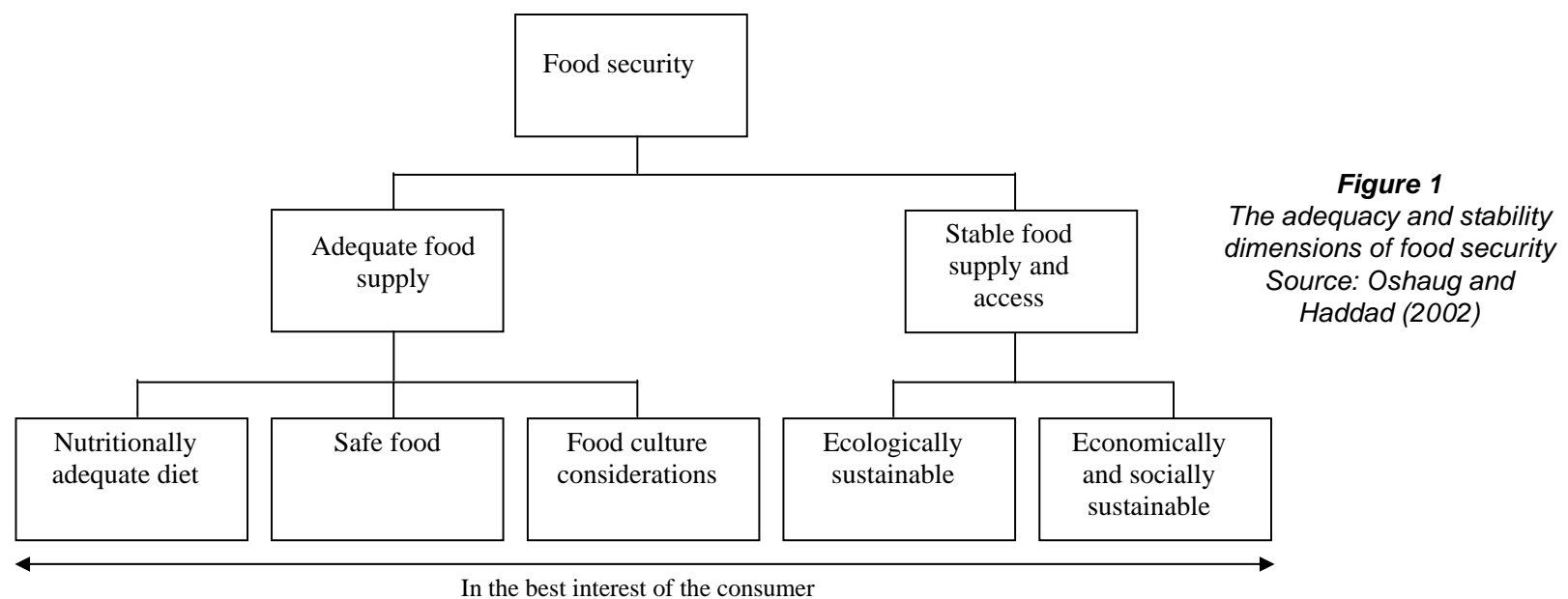

the adequacy dimension in Fig. 1) and the agricultural sector, particularly smallholder agriculture, because this addresses the availability and access dimensions for the rural African household, known to be at particular nutritional risk for malnutrition.

\section{Nutrition-related aspects of smallholder agricul- ture in South Africa}

Agriculture can affect human nutrition in a number of ways. These impacts can be generic (i.e. not sector-specific, thus acting indirectly) and/or specific (i.e. if food - not something else - is produced, thus acting directly) as shown in Table 1 . Generically, agricultural activities have become important alternative means of supplementing family income in rural areas in South Africa (Ngqaleni and Makhura, 1995). Over one third of rural households continue to engage in agricultural production, making it the third most important livelihood tactic used in rural areas after remittances and wages from low-skilled jobs (Machethe, 2004).
On the specific side, whilst food production and nutrition are intuitively linked, this relationship does not follow a direct course. Frameworks (e.g. Savage King and Burgess, 1993; FAO, 1997; Perrin, 1996; Boyle, 2003) depicting the path from agricultural production to nutrition tends to be either over-simplified, suggesting a linear relationship of cause and effect, and implying that a supply-driven approach would offer the (full) solution, or they are so complex that they cease to be useful. Whilst some of these limitations may also apply to the agriculture-nutrition advantage framework (Fig. 2, Johnson-Welch et al., 2005), it takes a new approach by accounting for gender and sustainable livelihoods. At the same time it elaborates on the agriculturefood security side of the causes of malnutrition, yet at the same time incorporates the well-known UNICEF conceptual framework (see Faber and Wenhold, 2007), which is officially adopted by South Africa.

Within the domain of agriculture the term smallholding refers to a farm operation that is small in size. In South Africa predominantly African people practise smallholder agriculture (Ortmann and Machete, 2003) and as a result the term small-

\begin{tabular}{|c|c|}
\hline \multicolumn{2}{|c|}{$\begin{array}{c}\text { TABLE } 1 \\
\text { Generic and specific effects of agriculture on nutrition }\end{array}$} \\
\hline \multicolumn{2}{|l|}{ Generic effects } \\
\hline Income generation & $\begin{array}{l}\text { An increase in income enables individuals to diversify the diet and also to buy } \\
\text { more non-foods, and this tends to imply a greater dietary quality. It is important } \\
\text { not to equate increases in income with increases in nutrition. }\end{array}$ \\
\hline Time allocation & The activities can affect the parents' time available for child care. \\
\hline Household decision making & $\begin{array}{l}\text { The activities can affect the bargaining power of household members, which can } \\
\text { influence household decisions. }\end{array}$ \\
\hline Energy and nutrient expenditure & The activities can affect the individual's energy and nutrient expenditure. \\
\hline Health environment & The activities can affect the health risks within the environment. \\
\hline \multicolumn{2}{|l|}{ Specific effects } \\
\hline Decline in food prices & In general, increased food production will lead to lower food prices. \\
\hline Own consumption & People's food consumption can be affected by what they grow. \\
\hline Processing and preparation & $\begin{array}{l}\text { Post-harvest activities such as storage, commercial and in-home processing and } \\
\text { preparation can affect nutrient availability through (i) increasing the general use } \\
\text { of nutrient-rich foods, (ii) increasing the nutrient density of foods consumed by } \\
\text { infants, and (iii) decreasing nutrient losses from the processing of widely avail- } \\
\text { able foods. }\end{array}$ \\
\hline Plant breeding & $\begin{array}{l}\text { To increase the micronutrient content of the crop, decrease the concentration of } \\
\text { absorption inhibitors such as phytic acid and increase the concentration of pro- } \\
\text { moter compounds through traditional breeding and biotechnology. }\end{array}$ \\
\hline
\end{tabular}

Source: Haddad (2000) 
Figure 2

The agriculture-nutrition advantage framework Source: Johnson-Welch et al. (2005)

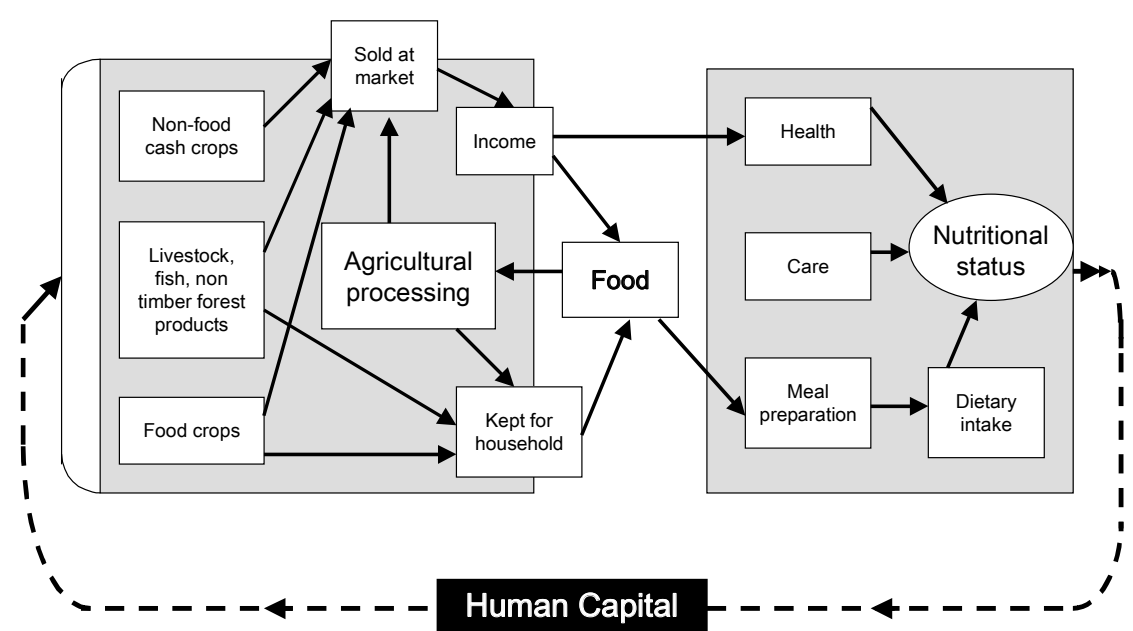

holder agriculture is often used when referring to the farming that is practised by African people in this country. The diversity encountered in South African smallholder farming is very wide as a result of differences in scale, agro-ecology, farming object, access to land and tenure system, markets, traditions and the availability of alternative livelihood options, making it difficult to generalise.

Traditionally African people practise mixed farming, which involves the production of both crops and animals on three types of land, namely residential, arable and commonage. Residential land is used for home gardening. Where settlements have been planned, the residential land is usually about 0.1 ha in size, but in parts of the Transkei region in the Eastern Cape the norm is 0.4 ha (Mkile, 2001). Where traditional tenure still applies, as is the case in selected parts of the Transkei region and in much of the Zululand region of KwaZulu-Natal, residential sites and associated home gardens can be several hectares in size (Andrew and Fox, 2003). Of the three types of land available for farming, the residential land tends to be used most intensively for several reasons. Situated close to the dwelling they are within easy reach when time for gardening is available. They are usually fenced in, which protects the crop against damage by livestock. Livestock kraals are also located on the residential site, ensuring easy access to animal manure to fertilise the gardens. Access to water for occasional irrigation, particularly at planting, is often also available through rooftop harvesting of water or as a result of the proximity of standpipes. Crop selection in home gardens tends to be associated with garden size. Large gardens are typically used for the production of staple food crops, mainly maize, dry beans, pumpkins and melons, whilst small gardens often feature vegetables and tuber crops, such as potatoes and sweet potatoes, but maize is also common. When home gardening is aimed primarily at producing crops for home consumption, the primary potential impact of small gardens on human nutrition is on the intake of micro-nutrients (Khosa, 2003). The main impact of crop production in large gardens is the same as field crop production, namely to provide energy (from cereals, roots and tubers) and protein (from legumes).

Bembridge (1984), Steyn (1988), De Lange (1991) and ARDRI (2001) reported that between $47 \%$ and $97 \%$ of rural households in the Eastern Cape kept an average of 5 to 13 chickens. Khosa (2003) recorded an average holding of 11 chickens by $34 \%$ of households in two settlements in Limpopo Province. During daytime scavenger chickens roam freely around the settlement, whilst at night they are usually locked up for security reasons. The food that the chickens obtain from the land is often supplemented with leftovers from homestead meals and poor-quality grain in cases where keepers are involved in grain production (McAllister, 2001). The scavenger system is efficient in the sense that input levels are very low or non-existent, making it ideally suited for poor rural people, but production levels are also low and the availability of food limits the total number of birds that can subsist within a particular settlement (Smith, 1990). Scavenger chickens produce between 20 and 30 eggs/hen·yr of which most are left to hatch because they are not found in time. The majority of chicks that are hatched die. Smith (1990) reported a mortality rate of $80 \%$ in scavenger systems in Nigeria and Sudan. Reproduction in a scavenger poultry system allows for the annual off-take of about one-third of the birds without causing a decline in the overall population. Practically this means that on average rural keepers of scavenger chickens obtain 3 to 4 chickens per year for home consumption or sale and probably fewer than 100 eggs.

Many rural households keep a few pigs, which they also rear by means of a scavenger system. Among rural people in South Africa keeping pigs is less common than keeping poultry. In the Eastern Cape, where there are apparently no taboos associated with the consumption of pork, an estimated $56 \%$ of households keep an average of 2 pigs at a time (Bembridge, 1984; Steyn, 1988; De Lange, 1991; ARDRI, 2001). The same average size of pig holding has been reported for the Limpopo Province (Baber, 1996; Khosa, 2003), but the proportion of households keeping pigs (2\%) was much lower than in the Eastern Cape. Homeslaughter of livestock is common among rural households, but the selling of meat of slaughtered animals is not. Pork is the main exception. For example, in the Eastern Cape, pigs are the only livestock species that rural people slaughter for the purpose of selling meat (Steyn, 1988; Mafu, 1998).

Arable allotments, which typically range in size between 1 ha and 5 ha, are used to produce staple food crops. In the south these consist primarily of maize, dry beans, pumpkins and melons, which are often produced using a mixed cropping system (Silwana, 2000). In the north field crop diversity tends to be wider and besides maize, pumpkins and melons, grain sorghum, millet, bambara groundnuts, cowpeas and groundnuts are also grown (Baber, 1996). The size of the harvests varies widely, but the aim of farmers is usually to produce enough to meet the consumption requirements of their households (Van Averbeke and Perret, 2004). The produce is usually stored on site and storage losses are considerable. ISER (2000) estimated that about onethird of the maize grain harvested by farmers in the Transkei region had to be discarded or fed to animals because of damage 
by weevils and other causes. Furthermore, Fusarium verticillioides (a fungus causing Fusarium ear rot in maize) on homegrown maize has been shown to be a health hazard in the Transkei (Theunissen, 2002). Arable lands also play an important role in livestock production, providing fodder to animals in the form of crop residues and weeds during the fallow period (Bennett, 2002) and as a source of wild leafy vegetables (McAllister, 2001).

The commonage is used for the production of small and large livestock, mainly cattle, goats and sheep and also for the collection of plant materials for various uses including food in the form of fruit and edible herbs (Schackleton et al., 2000; Schackleton, 2003). For various reasons cattle are the preferred type of livestock among African farmers. The distribution pattern in terms of herd size reflects a large majority of households with a few animals and a small group that owns many (Bembridge, 1979; Tapson and Rose, 1984; Düvel and Afful, 1997; Ntshona and Turner, 2002; Ainslie, 2002, 2003). Smallholder herds are characterised by a high proportion of oxen and a low proportion of cows and heifers (Bembridge, 1979). African farmers keep cattle for multiple reasons, including utilitarian, investment, religious, cultural and social. Reasons vary among farmers, are influenced by local conditions and evolve over time (Düvel and Afful, 1997; Kepe, 2002). Obtaining milk for home consumption is an important reason why African people keep cattle from a nutritional perspective (Tapson and Rose, 1984; Monde, 2003). Lactating cows are awarded priority status when crop residues are available, but few farmers actively feed their lactating animals (Bembridge, 1984; Tapson and Rose, 1984; Steyn, 1988; Bennett, 2002). Generally, lactating cows in smallholder herds do not produce much milk. Indications are that lactating cows in good condition produce about $6 \ell$ of milk per day over a period of eight months (Brown, 1969). Of this total production, half is needed to nourish the calf, leaving approximately $3 \ell$ per day for human consumption. The available estimates indicate that average milk yields for home consumption or sales range between $1.7 \ell$ and $2.3 \ell$ per lactating animal per day (Tapson and Rose, 1984; Bembridge, 1984; Steyn, 1988). Tangka et al. (2000) provide evidence from several studies in different parts of the world that the regular intake of cows' milk has a positive effect on the nutritional status of children in developing countries. Home slaughter of cattle is another practice that can potentially impact on human nutrition, but home slaughter of cattle among African people in South Africa is almost exclusively associated with ceremonies and rituals that are linked to ancestral beliefs. This results in the carcass being consumed by large numbers of people, spreading the nutritional benefits widely but thinly. Cultural practices determine who eats what and when, illustrating the potential impact of intra-household and intra-community distribution of food on the actual dietary intake of the individual.

Goats perform a similar function as cattle in smallholder farming. They are favoured for ritual slaughter, because as with cattle they make a lot of noise during the kill, calling on the ancestors. Goats are also milked but opinions about the taste of goat milk vary (Mafu and Masika, 2002). In some African rural communities milking of goats is viewed as an indication of poverty. Reported average milk yields from goats are $300-700 \mathrm{~m} \ell / \mathrm{d}$ in the Eastern Cape (Mafu and Masika, 2002) and 200-1 $000 \mathrm{~m} \ell / \mathrm{d}$ in the tropics (Peacock, 1996).

Smallholder production of sheep is mainly limited to the Eastern Cape. Relative to cattle and goats, ownership of sheep among rural households in the Eastern Cape is less common ( $29 \%$ overall), but the average number of animals per keeper is substantially higher (18 animals) (Bembridge, 1984; Steyn, 1988; De Lange, 1991; ARDRI, 2001). The animals are primarily kept for two purposes, namely meat and wool. Milking of sheep is rare. Local smallholders more easily slaughter a sheep for the purpose of eating meat than is the case with cattle or goats. As a result, a major portion of the value derived from sheep is in the form of meat for home consumption (Steyn, 1988).

This overview of smallholder farming in South Africa suggests that farming has an important role in human nutrition in the rural areas of the country, but the assessment of the impact thereof has received limited attention. Results of studies done in South Africa yielded contradictory results. Schmidt and Vorster (1995) determined whether or not participation in irrigated vegetable production on an $18 \mathrm{~m}^{2}$ plot improved the nutritional status of households, particularly among children, in a semiarid setting in the Northwest Province but their results were inconclusive. In contrast, an experimental study done by the Medical Research Council in a rural village in KwaZulu-Natal showed that home-gardens that focused on dark-green leafy and yellow/orange vegetables resulted in an increased dietary intake of vitamin A, riboflavin, vitamin $\mathrm{B}_{6}$ and vitamin $\mathrm{C}$ (Faber et al., 2002a), and ultimately an improvement in vitamin A status of children (Faber et al., 2002b).

Relating variables describing agricultural production of households in KwaZulu-Natal to the anthropometric data of children aged 0 to 60 months that formed part of these households, Kirsten et al. (1998) found that agriculture improved the nutritional status of households only when production generated substantial monetary income, or when it enabled a substantial reduction in household food expenditure, enabling households to purchase energy-dense foods, fruits and vegetables, which is an indirect (generic) rather than a direct (specific) impact (Table 1).

Smallholder farming can potentially impact on human nutrition by providing a variety of foods in sufficient quantities to enable all household members to eat a nutritionally adequate diet. This demands closer cooperation between nutrition and agriculture, which thus far appears to have been limited in South Africa. It is promising though that there are examples of successful collaboration between nutrition and agricultural research. For example, nutritionists of the Medical Research Council and agriculturists of the Agricultural Research Council have been working together since 1998, focusing on gardening interventions to address malnutrition in South Africa.

\section{Linking agricultural interventions to nutrition}

The agriculture-nutrition advantage framework (Fig. 2) shows the link between agriculture and nutrition. The strength of the link is affected by numerous factors, including crop diversification, gender issues and nutrition education and promotion.

\section{Crop diversification}

Greater and more sustained yields may increase the potential access of households to a larger food supply. However, greater yields through mono-crop production of low nutrient content crops do not necessarily translate into adequate nutrition. Diversification of crops will help communities to be more self-reliant in respect of nutritional problems. Increasing the variety of foods in the diet across and within food groups is recommended internationally (FAO/WHO, 1998) and in the South African food-based dietary guidelines (Maunder et al., 2001). Results of the National Food Consumption Survey showed that the diets of 
many South African households have low dietary variety, particularly those households with a low income (Labadarios et al., 2000). Achieving the goal of dietary diversity will be most difficult for low-income households because of the constraints of poverty. Affordability and availability have been identified as major constraints, particularly with regard to fruit and vegetable consumption (Love et al., 2001). The availability of a greater variety of nutritious foods at community and household level can be increased through mixed cropping; the introduction of new crops; the promotion of underexploited traditional food crops; and home gardens (FAO, 1997; Faber and Wenhold, 2007).

\section{Gender sensitivity}

Rural and peri-urban agricultural projects that include gender issues have a greater likelihood of effecting a positive nutritional change (Berti et al., 2004). While both men and women are engaged in agricultural production, marketing and post-harvest processing, and earning income, women and girls tend to have the primary responsibility for family nutrition. A gender-sensitive approach will have two dimensions - firstly, considering the role of the men and the women in agriculture; and secondly, considering the role of the men and the women in the household (Jiggins et al., 1997). Gender analysis will take into account factors such as women's roles as agricultural producers and caregivers, their time and labour allocation, and their decision-making roles relative to the use and distribution of resources and benefits within the household (Johnson-Welch et al., 2005). For example, in Uganda a gender-informed approach was used to identify preferred agronomic characteristics of beans. Men preferred varieties that were high-yielding with market value, while women, because of their time and labour constraints, preferred varieties that were easier to process (cited in Johnson-Welch et al., 2005).

Technologies that reduce the amount of time that women spend on agricultural activities will allow them to spend more time on household matters such as family nutrition. In Tanzania, for example, the use of solar dryers improved labour productivity of women and children because they could do other things while the drying was in progress, whereas the traditional method of drying required their presence to keep animals and insects away from the food (Mulokozi et al., 2001).

The responsibilities and privileges of men and women vary along socio-cultural and socio-economic lines. Rural women should therefore not be viewed as a homogeneous social classification, and gender relationships in households should not be generalised. Policies and services for women and agriculture should capture the diversity across communities. Agricultural extension services therefore need to be adapted to local conditions (Jiggins et al., 1997).

\section{Nutrition education and promotion}

A review by Ruel (2001) showed that strategies to promote increased production of micronutrient rich foods are more effective when combined with a nutrition education intervention, which ensures that increased household food supply and income translates into improved dietary quality. Nutritional interventions generally focus on increasing knowledge, changing attitudes, and improving practices related to the three pillars of good nutrition, namely health, care, and dietary intake.

Nutrition education can stimulate the demand for certain foods, but the individuals must have the means and opportunities to act on that knowledge. In the Ndunakazi project (Faber et al., 2002a), caregivers of all the children were exposed to nutrition education, regardless whether they had a project garden or not. Yet children from households with project gardens had a better vitamin A status than children who did not have a project garden at household level (Faber et al., 2002b). This suggested that access to a supply was critically more important than education without ready access.

\section{Critical issues in linking agricultural interventions to nutrition}

Action-orientated strategies should go beyond the question of "why" an agriculture-nutrition-linked, gender-informed approach should be used, to "how" it could be implemented (Johnson-Welch et al., 2005). Measures to enhance the potential nutritional outcomes of agricultural interventions are listed in Table 2 (see next page).

\section{Linking water to household food security and nutrition}

\section{Water and food security}

Food security is the outcome of many interrelated factors, one of which being water, an essential resource for food production. People's access to water in rural areas, and the price of water, affects their food security for the following reasons (Hubbart, 1995):

- Rural water costs tend to be high and unstable, whether in monetary terms or in the time and effort required by households to fetch water, thus influencing their real incomes. For example, Khosa (2003) reports that households in Sekuruwe and Molekane (Limpopo Province) paid R0.50 for $20 \ell$ potable water obtained from private boreholes and travelled long distances to collect water from rivers or springs for purposes other than drinking and cooking. Rural clean water sources are often vulnerable to droughts and floods, leading to increased costs of obtaining clean water at times when food prices typically are also likely to be high.

- Water-related local diarrhoeal diseases reduce food absorption. Nearly $50 \%$ of South African children do not have access to clean safe water and large numbers of children are hospitalised annually for complications as a result of diarrhoeal disease (King et al., 2006). In South Africa diarrhoeal diseases are the third leading cause of death for South African children younger than five years (Bradshaw and Nannan, 2006).

- Access to water for livestock and particularly for the irrigation of crops, including food crops, is one of the ways poverty and food insecurity can be reduced in rural areas. This has resulted in water being called the dividing line between poverty and prosperity, as it is a cross-cutting tool for the achievement of the millennium development goals.

Food production is the most water-intensive activity in society and water is the number one food-limiting factor in many parts of Asia and sub-Saharan Africa. Agriculture accounts for $70 \%$ of the worldwide human fresh water use (Gerbens-Leenes and Nonhebel, 2004) and this figure can be as high as $90 \%$ in developing countries (SIWI-IWMI, 2004). Whilst about $50 \ell$ water/person'd is the recommended minimum for household use, 70 times as much $(3500 \mathrm{l} / \mathrm{d})$ is needed to meet the consumptive water use for producing a projected human diet consisting of $3000 \mathrm{kcal}$ (12 $600 \mathrm{~kJ}$ ) per day for one person (SIWI IFPRI 


\section{TABLE 2}

Measures to enhance the potential nutritional outcomes of agricultural interventions

Agricultural projects must focus on specific nutritional problems: Nutritionally vulnerable groups should grow crops to meet their particular nutritional needs. Collaboration between nutritionists and agronomists is needed to ensure that community-based agricultural projects are based on the food needs and nutritional requirements of the community.

Conceptual framework: A conceptual framework that lays out the pathways between nutrition and agriculture should be used to guide the design, implementation and evaluation of the project.

Multidisciplinary team: Partners with complementary skills should work together towards a common goal. When working across disciplines, individuals must be sensitised to the terminology, concepts and priorities of the other disciplines.

Promote indigenous food crops: People are accustomed to them, and know how to cultivate and prepare them.

Diversify food production: The availability of a greater variety of nutritious foods at community and household level can be increased through (i) mixed cropping, (ii) the introduction of new crops, (iii) the promotion of under-exploited traditional food crops; and (iv) home gardens.

Expand seasonal availability of food: Can be achieved through staggered planting, processing and preserving.

Processing: Appropriate processing and storage of fruits and vegetables is important to minimize nutrient losses, reduce waste and post-harvest losses, extend seasonal availability and generate employment.

Promote vegetatively propagated crops: Crops that can be vegetatively propagated reduce money spent on seeds and are easy to multiply and distribute. Local seed multiplication creates employment. This needs good managerial and quality control.

Agricultural and health extension officers: Nutritional aspects need to be included in the training and daily activities of both agricultural and health extension officers; they should be knowledgeable in basic nutrition and provide information on nutritional benefits of gardening.

Participatory process: Effective use of a participatory process allows for a wide range of people to be involved in the decision-making process regarding the planning, implementation, monitoring and evaluation of the project. Hunger and under-nutrition are most visible at the individual and household levels; community input is therefore invaluable. Involvement of farmers will ensure that indigenous knowledge complements formal scientific knowledge.

Involve women: Involving women will ensure that their needs and concerns are considered and that project activities do not become a burden to them. It increases their participation, and ultimately success of the project.

Nutrition education as part of the agricultural intervention: Nutrition education is crucial to ensure that increased food supply translates into improved dietary quality, and ultimately improved nutritional status. Nutrition messages should be tailored to the community's needs and should relate to the agricultural intervention.

Measure impact: Use various research methods to show impact. For example, use both qualitative and quantitative data collection methods; select an outcome indicator sensitive to the intervention, including changes in agricultural production. Compare results within and across control and experimental groups over time.

Evaluate sustainability: Agricultural projects that invest broadly in human and other types of capital have a greater likelihood of effecting a positive nutritional change, but it is not clear what is necessary to sustain the nutritional benefits in the years after the intervention period.

Sources: FAO (1997:chapter 50); Bonnard (1999); FAO (2001); Hagenimana et al. (2001); Ruel (2001); Berti et al. (2004)

IUCN IWMI, 2005:7). Large volumes of water are transformed into vapour during production in the form of plant transpiration and evaporation from fields, canals, reservoirs and high water tables (SIWI-IWMI, 2004). Water, however, is the main limiting resource in South African crop production, and this limits the potential to increase food production in the dry rural regions where the prevalence of under-nutrition is high (Laker, 2004). At the global level, Rosegrant et al. (2002) predicted that, if current water policies continue, farmers will find it difficult to meet the world's food demands and projected that the global yield growth rate for all cereals will decline from $1.5 \%$ achieved between 1982 and 1995 to $1.0 \%$ per year during the period 1995 to 2025.

Feeding more people with the same amount of water thus appears to be an important consideration for the promotion of food security. Methods of increasing production without using more water include promoting crops that are well adapted to harsh climatic and growth conditions, breeding drought-tolerant crops, changing agronomic and field practices, applying lowcost supplementary irrigation technologies for rain-fed areas, reutilising water, introducing innovative water pricing systems and incentives, water harvesting, using labour- and/or waterefficient irrigation technologies, etc. (Welch and Graham, 2002; Khosa, 2003; Kundhlande et al., 2004; SIWI-IWMI, 2004:2528; SIWI IFPRI IUCN IMWI, 2005:14; Spreeth et al., 2004; IFAD, 1992a,b; Daka, 2001; Laker, 2004; 2006).

An elaboration of the first-mentioned of the above approaches could be the purposeful cultivation of indigenous plants known to be water-productive. The harvesting of wild resources has been identified as the 'least visible and most underestimated economic activity“ in rural communities, contributing to the direct-use values of sustainable livelihoods (Turner, 2004:48-9). Recently, however, a revived interest in the nutritional potential of African green leafy vegetables appears to be imminent (Flyman and Afolayan, 2006; Modi et al., 2006; Odhav et al., 2007).

\section{Nutritional water productivity}

In the context of crop production water use, water requirement, water productivity or water use efficiency are all concepts that refer to the ratio of crop yield to water consumed (production per unit of water depleted) expressed as $\mathrm{kg} \mathrm{crop} / \mathrm{m}^{3}$ water (Renault and Wallender, 2000). For a particular crop this form of productivity depends on many factors, including climate, geographical location and duration of the cropping season (SIWI-IWMI, 2004). Thus, Gerbens-Leenes and Nonhebel (2004) differentiate between a crop-specific and a site-specific water flow. The latter refers to the local hydrological system and the factors mentioned above. It follows that any information on 'total' water use of a crop obtained at a specific site cannot necessarily be used for other locations. Tables setting out water requirements to produce a kilogram of various food items should thus be interpreted with this in mind. Nevertheless, regardless of the geographical site, available information shows that much more water is needed to produce animal-based foodstuffs compared to plant-based commodities (SIWI-IWMI, 2004; Renault and Wallender, 2000).

An emerging concept, which takes water productivity a step closer to human nutrition, is nutritional water productivity 
(NWP). It quantifies nutrition per volume water expressed as nutritional units per $\mathrm{m}^{3}$. The nutritional units refer to energy (kJ) or nutrients (Renault and Wallender, 2000). An indication of the NWP (in terms of energy and protein) of various foods in the Californian environment is given in Table 3. Again, whilst the absolute values may not be applicable to South Africa, the trends among foods are relevant. The table shows that energy productivity for animal foods is low and conversely it is high for cereals, ranging from $428 \mathrm{~kJ} / \mathrm{m}^{3}$ for beef to $23629 \mathrm{~kJ} / \mathrm{m}^{3}$ for potatoes. The high energy productivity of maize and potatoes can be taken even further: if, for example, a human energy requirement of $2700 \mathrm{kcal} / \mathrm{d}(11340 \mathrm{~kJ} / \mathrm{d})$ is assumed, then these two commodities could cover the daily energy needs with much less than $1 \mathrm{~m}^{3}$ water/cap·d (Renault and Wallender, 2000).

Protein productivity of animal products, which are generally considered important sources of protein, ranges from $10 \mathrm{~g} / \mathrm{m}^{3}$ of water for beef (i.e. about $13 \%$ of a hypothetical human adult protein requirement of $75 \mathrm{~g} / \mathrm{d}$ ) to about $40 \mathrm{~g} / \mathrm{m}^{3}$ for eggs and milk (i.e. about $53 \%$ of the hypothetical requirement). Potatoes perform very well: the protein productivity is $150 \mathrm{~g} / \mathrm{m}^{3}$ (i.e. it would supply $75 \mathrm{~g}$ of protein with only $0.5 \mathrm{~m}^{3}$ of water) (Renault and Wallender, 2000).

Diets are, however, not composed of individual foods. Based on the NWP figures of Table 3, the theoretical water requirements of the national American diet and the increase in water productivity that could be achieved if the current diet were adjusted to contain more plant-based commodities have been calculated by Renault and Wallender (2000). They conclude that if Americans reduced their current annual intake of all animal products by $50 \%$ and replaced these with vegetable products, and also reduced oil intake to match energy intake targets, then the water requirements would decrease from the current 5.40 to $3.40 \mathrm{~m}^{3} /$ person $d$ (equivalent to a $59 \%$ increase in water productivity).

In a similar vein the SIWI-IWMI study claims that using currently prevailing (global) production methods for land and water management practices, today's diets, on average, represent a depleting water use of $1200 \mathrm{~m}^{3} /$ person·yr, with large variations between different regions. These vary from $600 \mathrm{~m}^{3} / \mathrm{yr}$ in the poorest regions to $1800 \mathrm{~m}^{3} / \mathrm{yr}$ in regions with the highest meat-based intakes. Thus, for an acceptable nutritional intake including $80 \%$ plant and $20 \%$ animal sources, about $1300 \mathrm{~m}^{3}$ water/person-yr would be needed, whereas a purely vegetarian diet requires about half as much (SIWI-IWMI, 2004:23).

Such comparisons must take natural resource realities into account, however. The fact is that mainly because of very low rainfall over most of South Africa and poor quality soils and/ or steep slopes in many higher rainfall areas, only 13\% (about $14 \times 10^{6}$ ha) of South Africa is arable, i.e. suitable for crop production. The rest can be used only for extensive livestock production from rangeland (e.g. Laker, 2004; 2006). Only 3\% of the country is classified as having high-potential arable land.

In small-scale agriculture, especially vegetable production, a lot more can be produced with the same amount of water if highly efficient, water saving technologies are used. Clay pot irrigation, which is used in various African countries, e.g. Zimbabwe, Zambia and Burkina Faso, and various other parts of the world, is one such technology (Daka, 2001; Laker, 2006). In Zambia irrigation water savings of as much as $70 \%$ were obtained in small-scale vegetable production with this method, compared with conventional irrigation systems (Table 4). This would, for irrigation water, mean at least a two- to threefold increase in nutritional water productivity for the same crops. For none of these crops were yields lower with the clay pot system

\begin{tabular}{|c|c|c|c|}
\hline \multicolumn{4}{|c|}{$\begin{array}{c}\text { TABLE } 3 \\
\text { Nutritional water productivity of } \\
\text { various foods }\end{array}$} \\
\hline \multirow[t]{3}{*}{ Food } & \multicolumn{3}{|c|}{ Nutritional water productivity } \\
\hline & \multicolumn{2}{|c|}{ Energy } & Protein \\
\hline & $\mathrm{kcal} / \mathrm{m}^{3}$ & $\mathrm{~kJ} / \mathrm{m}^{3 *}$ & $\mathrm{~g} / \mathrm{m}^{3}$ \\
\hline \multicolumn{4}{|l|}{ Cereals } \\
\hline Wheat & 2279 & 9572 & 74 \\
\hline Rice & 1989 & 8354 & 49 \\
\hline Maize & 3856 & 16195 & 77 \\
\hline \multicolumn{4}{|c|}{ Legumes, nuts and oils } \\
\hline Pulses (beans) & 1188 & 4990 & 76 \\
\hline Treenuts & 521 & 2188 & 14 \\
\hline Groundnuts & 2382 & 10004 & 111 \\
\hline Soybean oil & 547 & 2297 & 0 \\
\hline Cotton seed oil & 721 & 3028 & 0 \\
\hline \multicolumn{4}{|c|}{ Vegetables, roots and tubers } \\
\hline Tomatoes & 1416 & 5947 & 65 \\
\hline Onions & 2259 & 9479 & 85 \\
\hline Sugar beets & 2520 & 10584 & 0 \\
\hline Potatoes & 5626 & 23629 & 150 \\
\hline \multicolumn{4}{|l|}{ Fruit } \\
\hline Oranges & 663 & 2785 & 13 \\
\hline Lemons & 504 & 2117 & 0 \\
\hline Grapefruit & 553 & 2323 & 0 \\
\hline Bananas & 432 & 1814 & 11 \\
\hline Apples & 1140 & 4788 & 6 \\
\hline Pineapples & 1136 & 4771 & 0 \\
\hline Dates & 731 & 3070 & 0 \\
\hline Grapes & 1356 & 5695 & 14 \\
\hline \multicolumn{4}{|l|}{ Animal products } \\
\hline Beef & 102 & 428 & 10 \\
\hline Pork meat & 408 & 1714 & 21 \\
\hline Poultry meat & 330 & 1386 & 33 \\
\hline Eggs & 519 & 2180 & 41 \\
\hline Milk & 659 & 2768 & 40 \\
\hline Butter & 404 & 1697 & 1 \\
\hline
\end{tabular}

*kcal $x 4.2$ (rounded to whole figures)

Source: Selected information from Renault and Wallender (2000)

\begin{tabular}{|c|c|c|c|}
\hline \multicolumn{4}{|c|}{$\begin{array}{l}\text { TABLE } 4 \\
\text { Irrigation water use of some vegetable crops under } \\
\text { clay pot and watering can irrigation and water sav- } \\
\text { ings by using clay pot irrigation (From Daka, 2001)* }\end{array}$} \\
\hline \multirow[t]{2}{*}{ Crop } & \multicolumn{2}{|c|}{$\begin{array}{l}\text { Growing season crop } \\
\text { irrigation water use }(\mathrm{mm})\end{array}$} & \multirow{2}{*}{$\begin{array}{l}\text { Irrigation } \\
\text { water saving } \\
\text { using clay } \\
\text { pots (\%) }\end{array}$} \\
\hline & Clay pot & Watering can & \\
\hline Beans & 203 & 450 & 55 \\
\hline Cabbage & 45 & 150 & 70 \\
\hline Cauliflower & 250 & 500 & 50 \\
\hline Maize & 200 & 500 & 60 \\
\hline Onion & 67.5 & 225 & 70 \\
\hline Rape & 180 & 400 & 55 \\
\hline Tomato & 195 & 650 & 70 \\
\hline
\end{tabular}

*The crops were grown in dambos with water tables

than with rope-and-bucket or sprinkler irrigation systems. For cauliflower, green maize and rape, yields with the clay pot system were, in fact, much higher than with the other two systems (Daka, 2001). 
Individual and societal food choices and preferences are influenced by many factors at a particular point in time and they also change over time - as part of global evolutions or revolutions, or based on personal decisions - for individuals, specific cultural groups and mankind as a whole (Kuhnlein and Receveur, 1996). Ultimately the food choices of individuals and populations result in consumer demand in the market place, which, in turn, is the major driver of food production. In this way food consumption trends will ultimately have implications on water and other environmental factors - something that consumers are largely ignorant or misinformed about. Raising water and environmental literacy could contribute to a change in food choices (SIWI-IWMI, 2004; ADA, 2001).

A consumption-based indicator of a nation's water needs is the so-called water footprint. It is defined as the total volume of freshwater, both green (i.e. moisture in the soil) and blue (i.e. water-associated irrigation from aquifers, rivers and lakes), that is used to produce the goods and services consumed by the people of the nation, i.e. both food and other goods and services (SIWI IFPRI IUCN IWMI, 2005:21). Behind any food basket (which reflects a consumer's food choice) there is a water footprint, which, in general, increases in line with the amount of food consumed and, even more pronounced, with the type and composition of the diet. Thus, not only increased production, but also increased demand for a diet with a sustainable water footprint is imperative.

\section{Conclusion}

For agricultural interventions to improve food security and nutrition, the intervention must have a well-designed agricultural component as well as a well-designed nutritional component, and these two components should be mutually reinforcing (Bonnard, 1999). Water is one of the essential resources to ensure food production. Feeding more people with the same amount of water is an important consideration for the promotion of food security and alleviation of malnutrition.

\section{'Fewer drops, more crops, most nutrition'}

\section{Acknowledgement}

This article is based on work that was supported by the Water Research Commission (WRC Project No K5/1579//4), but the authors accept full responsibility for any opinions, findings, conclusions or recommendations contained in this paper.

\section{References}

ADA POSITION (2001) Dietetics professionals can implement practices to conserve natural resources and protect the environment. J. Am. Diet.Assoc. 101 (101) 1221-1227.

AINSLIE A (2002) A review of cattle production in Peddie District. In: AINSLIE A (ed.) Cattle Ownership and Production in the Communal Areas of the Eastern Cape, South Africa. Research Report No 10. Programme for Land and Agrarian Studies (PLAAS), University of the Western Cape, Belville. 98-120.

AINSLIE A (2003) Farming cattle, cultivating relationships: Cattle ownership and cultural politics in Peddie District, Eastern Cape. Working paper No 34. Fort Hare Institute of Social and Economic Research, East London. 29 pp.

ANDREW M and FOX R (2003) Cultivation trends in the Transke and Ciskei: 1940-1996. Working paper No 1. Fort Hare Institute of Social and Economic Research, East London. 27 pp.

ARDRI (2001) Rural livelihoods survey in the Mbashe municipality: Final report. ARDRI, Univ. Fort Hare, Alice. 116 pp.

BABER R (1996) Current livelihoods in semi-arid rural areas of South
Africa. In: Lipton M, Ellis F and Lipton M (eds.) Land, Labour and Livelihoods in Rural South Africa. Indicator Press, Durban, South Africa. 269-302.

BEMBRIDGE TJ (1979) Problems of livestock production in the black states of Southern Africa and future strategy. S. Afr. J. Anim. Sci. 9 163-176.

BEMBRIDGE TJ (1984) A Systems Approach Study of Agricultural Development Problems in Transkei. Ph.D. Thesis, University of Stellenbosch. 685 pp.

BENNETT JE (2002) The Contribution of Arable Land Allocations to Cattle Production Systems in Communal Areas of Central Eastern Cape Province, South Africa. Ph.D. Thesis, Coventry University, UK. 403 pp.

BERTI PR, KRASAVEC J and FITZGERALD S (2004) A review of the effectiveness of agricultural interventions in improving nutrition outcomes. Public Health Nutr. 7 599-609.

BONNARD P (1999) Increasing the Nutritional Impacts of Agricultural Interventions. Food and Nutrition Technical Assistance Project, Washington DC. 20 pp.

BOYLE MA (2003) Community Nutrition in Action - An Entrepreneurial Approach ( $3^{\text {rd }}$ edn.) Thompson Wadsworth, UK. 655 pp.

BRADSHAW D and NANNAN N (2006) Mortality and morbidity among women and children. In: Ijumba P and Padarath A (eds.) South African Health Review 2006. Health Systems Trust, Durban. 107-126.

BROWN DL (1969) A Study of Animal and Crop Production Systems and Potential of the Bantu Ciskeian Territories. D.Sc.(Agric.) Thesis, University of the Orange Free State, Bloemfontein. 304 pp.

DAKA AE (2001) Development of a Technological Package for Sustainable Utilization of Dambos by Small-Scale Farmers. Ph.D. thesis, Univ. Pretoria, Pretoria. 225 pp.

DE KLERK M, DRIMIE S, ALIBER M, MINI S, MOKEONA R, RANDELA R, MODISELLE S, VOGEL C, DE SWART C and KIRSTEN J (2004) Food security in South Africa: key policy issues for the medium term. Human Sciences Research Council, Pretoria. $82 \mathrm{pp}$.

DE LANGE AO (1991) Peasant farming and the rural economy of the Eastern Cape. Agrekon 30 172-174.

DEPARTMENT OF AGRICULTURE (2002). The Integrated Food Security Strategy for South Africa. 17 July 2002. Department of Agriculture, Pretoria. 49 pp.

DÜVEL GH and AFFUL DB (1997) Towards an understanding of stocking rate decisions for communal rangelands in South Africa: the role of culture. S. Afr. J. Agric. Ext. 26 53-70.

FABER M and WENHOLD F (2007) Nutrition in contemporary South Africa. Water SA 33 (3) 393-400.

FABER M, VENTER SL and BENADÉ AJS (2002a) Increased vitamin A intake in children aged 2-5 years through targeted home-gardens in a rural South African community. Public Health Nutr. 5 11-16.

FABER M, PHUNGULA MA, VENTER SL, DHANSAY MA and BENADÉ AJS (2002b) Home gardens focusing on the production of yellow and dark-green leafy vegetables increase the serum retinol concentrations of 2-5-y-old children in South Africa. Am. J. Clin. Nutr. 76 1048-1054.

FAO (1996) World Food Summit, Rome. http://www.fao/org/docrep/003/ w3613e/w3613e00.htm (Accessed on 22/12/2005)

FAO/WHO (1998) Preparation and Use of Food-Based Dietary Guidelines. World Health Organization, Geneva. 99 pp.

FAO (1997) Agriculture, Food and Nutrition for Africa - A Resource Book for Teachers of Agriculture. Food and Nutrition Division, Food and Agricultural Organization of the United Nations, Rome. $412 \mathrm{pp}$.

FAO (2001) Incorporating Nutrition Considerations into Agricultural Research Plans and Programmes. Food and Nutrition Division, Food and Agricultural Organization of the United Nations, Rome. 36 pp.

FLYMAN MV and AFOLAYAN AJ (2006) The suitability of wild vegetables for alleviating human dietary deficiencies. S. Afr. J. Bot. 72 492-497.

GERBENS-LEENES PW and NONHEBEL S (2004) Critical water requirements for food, methodology and policy consequences for food security. Food Policy 29 547-64. 
HADDAD L (2000) Improving human nutrition through agriculture: the role of international agricultural research. SCN News 20 July. 12-16.

HAGENIMANA V, LOW J, ANYANGO M, KURZ K, GICHUKI ST and KABIRA J (2001) Enhancing vitamin A intake in young children in western Kenya: Orange- fleshed sweet potatoes and women farmers can serve as key entry points. Food and Nutr. Bull. 22 376387.

HUBBARD M (1995) Improving Food Security - A Guide for Rural Development Managers. Intermediate Technology Publications, London. 151 pp.

IFAD (1992a) Soil and Water Conservation in Sub-Saharan Africa - Towards Sustainable Production by the Rural Poor. IFAD, Free Univ., Amsterdam. 147 pp.

IFAD (1992b) Building on Traditions - Conserving Land and Alleviating Poverty. Video. IFAD, Rome.

ISER (2001) Willowvale Maize Milling Feasibility Study, 2001. Institute for Social and Economic Research, Rhodes University, East London. 71 pp.

JIGGINS J, SAMANTA RK and OLAWOYE JE (1997) Improving women farmer's access to extension services. In: BE Swanson, RP Bentz and AJ Sofranko AJ (eds.) Improving Agricultural Extension. A Reference Manual. Food and Agriculture Organization of the United Nations, Rome. URL: www.fao.org/docrep/w5830e/ w5830e00.htm (Accessed on 28/02/2006).

JOHNSON-WELCH C, MACQUARRIE K and BUNCH S (2005) A Leadership Strategy for Reducing Hunger and Malnutrition in Africa: the Agriculture-Nutrition Advantage. International Centre for Research on Women, Washington DC. 28 pp.

KEPE T (2002) The dynamics of cattle production and government intervention in communal areas of Lusikisiki District. In: Ainslie A (ed.) Cattle Ownership and Production in the Communal Areas of the Eastern Cape, South Africa. Research Report No 10. Programme for Land and Agrarian Studies (PLAAS), University of the Western Cape, Belville. 59-79.

KHOSA TB (2003) On-farm evaluation of the drum \& drip micro-irrigation system for vegetable production in home gardens. M. Tech. (Agric.) dissertation, Technikon Pretoria, Pretoria. 260 pp.

KING MS, MHLANGA RE and DE PINHO H (2006) The context of maternal and child health. In: Ijumba P and Padarath A (eds.) South African Health Review 2006. Health Systems Trust, Durban. 107-126.

KIRSTEN J, TOWNSEND R and GIBSON C (1998) Determination of agricultural production to household nutritional status in Kwa-ZuluNatal, South Africa. Dev. South. Afr. 15 (4) 573-587.

KUHNLEIN HV and RECEVEUR O (1996) Dietary change and traditional food systems of indigenous peoples. Ann. Rev. Nutr. 16 417-42.

KUNDHLANDE G, GROENEWALD DC, BAIPHETHI MN, VILJOEN MF, BOTHA JJ, VAN RENSBURG LD and ANDERSON JJ (2004) Socio-Economic Study on Water Conservation Techniques in Semi-Arid Areas. WRC Report No. 1267/1/04 Water Research Commission, Pretoria, South Africa. 241 pp.

LABADARIOS D, STEYN N, MAUNDER E, MACINTYRE U, SWART R, GERICKE G, HUSKISSON J, DANNHAUSER A, VORSTER HH and NESAMVUI EA (2000) The National Food Consumption Survey (NFCS): Children Aged 1-9 Years, South Africa, 1999. Department of Health: Directorate of Nutrition, Pretoria. $1046 \mathrm{pp}$.

LAKER MC (2004) Development of a General Strategy for Optimizing the Efficient Use of Primary Water Resources for Effective Alleviation of Rural Poverty. WRC Report No KV149/04. Water Research Commission, Pretoria, South Africa. 187 pp.

LAKER MC (2006) Soil productivity in irrigated agriculture, with special reference to South Africa. Paper presented at Southern Africa Regional Irrigation Association (SARIA) workshop, Pretoria, January 2006.

LOVE P, MAUNDER E, GREEN M, ROSS F, SMALE-LOVELY J and CHARLTON K (2001): South African food-based dietary guidelines. Testing of the preliminary guidelines among women in KwaZulu-Natal and the Western Cape. S. Afr. J. Clin. Nutr. 14 9-19.
MACHETHE CL (2004) Agriculture and poverty in South Africa: Can agriculture reduce poverty? Paper presented at the Overcoming Development Conference held in Pretoria, 28-29 October 2004.

MAFU VJ (1998) Small scale pig production in Eastern Cape communities. ARDRINews 1998 5-6.

MAFU VJ and MASIKA PJ (2002) Milk production from local goats, is it a viable option? ARDRINews 2002 6-8.

MAUNDER EMW, MATJI J and HLATSHWAYO-MOLEA T (2001) Enjoy a variety of foods - difficult but necessary in developing countries. S. Afr. J. Clin. Nutr. 14 S7-S11.

McALLISTER P (2001) Building the Homestead: Agriculture, Labour and Beer in South Africa's Transkei. African Studies Centre, Leiden, The Netherlands. 199 pp.

MKILE Z (2001) The Use and Agronomic Effectiveness of Kraal Manures in the Transkei Region of the Eastern Cape, South Africa. M.Sc. Agric. Dissertation, University of Fort Hare, Alice. 135 pp.

MODI M, MODI A and HENDRIKS S (2006) Potential role for wild vegetables in household food security: a preliminary case study in KwaZulu-Natal, South Africa. Afr. J. Food, Agric., Nutr. Dev. 6 (1) 1-13.

MONDE N (2003) Household food security in rural areas of central Eastern Cape: the case of Guquka in Victoria East and Koloni in Middledrift Districts. Ph.D. Thesis, University of Fort Hare, Alice. 263 pp.

MULUKOZI G, MSELLE L, MUGYABUSO J and JOHNSON-WELCH C (2001) Reducing subclinical vitamin A deficiency through women's adoption of appropriate technologies in Tanzania. Food Nutr. Bull. 22 400-407.

NGQALENI M and MAKHURA MT (1995) The role of women in the reconstruction of agriculture in developing areas: The case of the Northern Province. Agrekon 34 (4) 221-225.

NTSHONA Z and TURNER S (2002) The social and economic structure of livestock production systems in Maluti District. In: Ainslie A (ed.) Cattle Ownership and Production in the Communal Areas of the Eastern Cape, South Africa. Research Report No 10. Programme for Land and Agrarian Studies (PLAAS), University of the Western Cape, Belville. 80-97.

ODHAV B, BEEKRUM S, AKULA U and BAIJNATH H (2007) Preliminary assessment of nutritional value of traditional leafy vegetables in KwaZulu-Natal, South Africa. J. Food Comp. Anal. 20 430-435.

ORTMANN G and MACHETE C (2003) Problems and opportunities in South African agriculture. In: Nieuwoudt L and Groenewald J (eds) The Challenge of Change: Agriculture, Land and the South African Economy. Univ. Natal Press. 47-62.

OSHAUG A and HADDAD L (2002) Nutrition and agriculture. Brief 6 of 12. In: Nutrition: A Foundation for Development. ACC/SCN Geneva. 4 pp.

PEACOCK C (1996) Improving Goat Production in the Tropics: A Manual for Development Workers. Oxfam, Oxford, UK. 387 pp.

PERRIN P (1996) War and Public Health. International Committee of the Red Cross. Geneva. 446 pp.

RENAULT D and WALLENDER WW (2000) Nutritional water productivity and diets. Agric. Water Manage. 45 275-96.

ROSE D and CHARLTON KE (2002) Prevalence of household food poverty in South Africa: results from a large, nationally representative survey. Public Health Nutr. 5 383-389.

ROSEGRANT MW, CAI XIMING and CLINE SA (2002): Global Water Outlook to 2025 - Averting an Impending Crisis. A 2020 Vision for Food, Agriculture, and the Environment Initiative. International Food Policy Research Institute, Washington, DC. 26 pp.

RUEL M (2001) Can Food-Based Strategies help Reduce Vitamin A and Iron Deficiencies? A Review of Recent Evidence. International Food Policy Research Institute. Washington DC. 62 pp.

SAVAGE KING F and BURGESS A (1993) Nutrition for Developing Countries. Oxford University Press, Oxford. 460 pp.

SCHMIDT MI and VORSTER HH (1995) The effects of communal gardens on nutritional status. Dev. South. Afr. 12 (5) 713-725.

SHACKLETON SE, DZEREFOS CM, SHACKLETON CM and MATHABELA FR (2000). The use of and trade in indigenous edible fruits in the Bushbuckridge savanna region, South Africa. Ecol. Food Nutr. 39 225-245. 
SHACKLETON CM (2003) The prevalence of use and value of wild edible herbs in South Africa. S. Afr. J. Sci. 99 23-25.

SILWANA T (2000) The Performance of Maize/Bean and Maize/Pumpkin Intercrops under Different Planting Combinations and Weeding in Transkei, South Africa. M.Sc. Dissertation, University of Fort Hare, Alice. $122 \mathrm{pp}$.

SIWI-IWMI (2004) Water - More nutrition per drop. Stockholm International Water Institute. Stockholm. URL: www.siwi.org/downloads/More Nutrition Per Drop.pdf (Accessed on 30/04/2007). 36 pp.

SIWI, IFPRI, IUCN and IWMI (2005) 'Let It Reign. The New Water Paradigm for Global Food Security‘. Final report to CSD-13. Stockholm International Water Institute, Stockholm. URL: www.siwi.org (Accessed on 30/04/2007). 40 pp.

SMITH AJ (1990) Poultry. The Tropical Agriculturist Series. MacMillan Education Ltd. 218 pp.

SPREETH MH, SLABBERT MM, DE RONDE JA, VAN DEN HEEVER E and NDOU A (2004) Screening Of Cowpea, Bambara Groundnut And Amaranthus Germplasm For Drought Tolerance And Testing Of The Selected Plant Material In Participation With Targeted Communities. WRC Report No. 944/1/04. Water Research Commission, Pretoria, South Africa. 150 pp.

STEYN GJ (1988) A farming systems study of two rural areas in the Peddie District of Ciskei. D.Sc. (Agric.) Thesis, University of Fort Hare, Alice. 531 pp.

STEYN NP, ABERCROMBIE R and LABADARIOS D (2001) Food security - an update for health professionals. S. Afr. J. Clin. Nutr 14 98-102.

TANGKA FK, JABBAR MA and SHAPIRO BI (2000) Gender roles and child nutrition in livestock production systems in developing countries: A critical review. Socio-economics and Policy Research Working Paper 27. International Livestock Research Institute (ILRI), Nairobi, Kenya. 64 pp.

TAPSON DR and ROSE CJ (1984) An Investigation into the KwaZulu Cattle Industry. ARDRI Report 2/84. ARDRI, University of Fort Hare, Alice. 162 pp.

THEUNISSEN I(2002) Food for thought [Online]. Available from: http:// www.scienceinafrica.co.za/2002/december/food.htm(Accessed on 24/04/2007).

TURNER S (2004) Community-based natural resources management and rural livelihoods. In: Fabricius C, Koch E, Magome $\mathrm{H}$ and Turner S (eds.). Rights, Resources and Rural Development - Community-Based Natural Resource Management in Southern Africa. Earthscan, London, UK. 282 pp.

VAN AVERBEKE $\mathrm{W}$ and PERRET $\mathrm{S}$ (2004) The maize filière at Dzindi, a smallholder irrigation scheme in Limpopo Province. Proc. Int. Workshop on Water Resource Management for Local Development: Governance, Institutions and Policies. 8-11 November 2004, Aventura, Loskop Dam, South Africa. (CD ROM). WRC \& CIRAD, Pretoria. 387-400.

WELCH RM and GRAHAM RD (2002) Breeding crops for enhanced micronutrient content. Plant and Soil 245 205-14. 